\title{
MOLECULAR CHARACTERIZATION OF SWINE HEPATITIS E VIRUS FROM SOUTHEASTERN BRAZIL
}

\author{
Helder Henrique Paiva'; Valentina Tzaneva²; Rodrigo Haddad ${ }^{1}$; Jonny Yokosawa ${ }^{1 *}$ \\ ${ }^{1}$ Departamento de Análises Clínicas, Toxicológicas e Bromatológicas, Faculdade de Ciências Farmacêuticas de Ribeirão Preto, \\ Universidade de São Paulo, São Paulo, SP, Brasil; ${ }^{2}$ University Hospital, Trakia University. Stara Zagora, Bulgaria
}

Submitted: March 26, 2007; Returned to authors for corrections: September 22, 2007; Approved: November 15, 2007.

\begin{abstract}
Despite serological evidences of presence of hepatitis E virus (HEV) in humans or other animals, until this study the virus had not been detected and molecular characterization of the isolate that circulates in Brazil had not been described. Thus, we collected stool samples of young pigs and tested for presence of HEV RNA by RT-PCR, using primers for partial amplification of ORF2 sequence. Phylogenetic analysis with sequence obtained from the amplified products revealed that the HEV isolate identified here was most closely related to $\mathrm{HEV}$ isolates of genotype 3, which is commonly detected in HEV infected pigs. Nucleotide sequence analyses carried out with the entire amplified fragment, ORF2/ORF3 overlapping and ORF2 non-overlapping sequences showed highest identities with the US isolate of genotype 3. Similarly, amino acid sequence analyses done with the entire amplified fragment, ORF2 non-overlapping, ORF2 and ORF3 overlapping sequences also showed highest identities with the genotype 3 isolate. Presence, in Brazil, of HEV of genotype 4, which also infects pigs, as well as HEV strains that infect humans still remain to be detected and characterized.
\end{abstract}

Key words: viral hepatitis, hepatitis E virus, $\mathrm{HEV}$, molecular virology

\section{INTRODUCTION}

Hepatitis $\mathrm{E}$ is an enterically transmitted disease caused by the hepatitis E virus (HEV), which causes self-limiting acute illnesses and is responsible for a number of large epidemics in developing countries $(3,17)$.

HEV has been removed from the Calicivirus family and reclassified as a separate $H E V$-like genus. It is a non-enveloped virus of icosahedra symmetry and contains a positive strand RNA genome, which is about $7.2 \mathrm{~kb}$ long and has three open reading frames (ORFs) (40). ORF1 is about $5 \mathrm{~kb}$ long and codes for a non-structural protein that contains motifs of methyltransferase, protease, helicase and RNA-dependent RNA polymerase (18). ORF2 is about $2 \mathrm{~kb}$ long and codes for the capsid protein. ORF3 is 369 bases long, overlaps partially with ORF1 and ORF2 and codes for a protein of unknown function.

Sequences of HEV isolates have been grouped into four genotypes ( 1 to 4 ) (35). Genotype 1 contains sequences of isolates found mainly in Asia $(4,40,44,51)$. Genotype 2 contains a sequence of an isolate from an outbreak in Mexico (16). Genotype 3 groups sequences of isolates found in the Unites States, European countries, Japan and Argentina (10,30,32$34,37)$. Genotype 4 contains sequences of isolates found in China, Taiwan and Japan $(15,39,47,48)$.

Sporadic cases of hepatitis $\mathrm{E}$ have been documented in patients with no history travel to endemic areas for HEV $(9,14,35,36)$, raising concern about possible zoonotic transmission. High nucleotide sequence identities placed swine HEV isolates into genotypes 3 and 4 along with human HEV isolates $(15,24,39,45)$. Interestingly, swine HEV strain from US had higher sequence identity to a US human isolate than to either human or swine isolate sequences from Taiwan, and vice-versa (15). Furthermore, US HEV isolates from a patient and from swine have been experimentally transmitted to specific pathogen-free (spf) pigs and nonhuman primates $(25,26)$.

*Corresponding Author. Mailing address: Centers for Disease Control and Prevention - Division of Viral Hepatitis 1600 Clifton Rd. NE - Atlanta, GA 30329 - USA. Phone number: 404-639-4824. Fax number: 404-639-1563. E-mail: jey2@cdc.gov; j.yokosawa@uol.com.br 
Little is known about HEV in Latin America. Human HEV isolates of genotype 3 were found in Argentina $(21,34)$ and isolates of genotypes 2 and 3 were found in Mexico $(5,16)$. Recently, swine HEV detection in Argentina was reported (27). Presence of HEV in Latin America was evidenced by investigating prevalence of hepatitis $E$ by detection of serological markers. In these countries the prevalence ranged from $3.0 \%$ in Southeast Brazil (12) to 10.5\% in Mexico (1). Although serological evidences of HEV presence in Brazil have been published $(6,8,12,22,29,42)$, until this report, molecular characterization of $\mathrm{HEV}$ isolates circulating in Brazil has not been done.

The objectives of the present study were to detect the presence of HEV in swine in Sao Paulo State, Southeastern Brazil, the most industrialized region of the country, and to determine the molecular relationship between this isolate and those described in both humans and swine.

\section{MATERIALAND METHODS}

\section{Stool Specimens}

Swine stool samples were collected from eight pigs from one farm in the Northern region of Sao Paulo State, in Southeastern Brazil. Six pigs were approximately 40 days old and two were 60 days old. A $20 \%$ stool suspension was made with PBS pH 7.2 (31) from each stool sample and kept at $-70^{\circ} \mathrm{C}$.

\section{Nucleic acid extraction and detection by RT-PCR}

Nucleic acid was extracted from $150 \mu \mathrm{l}$ of stool suspension with MasterPure Complete DNA and RNA Purification Kit (Epicentre Technologies. Madison, WI) and resuspended with $20 \mu \mathrm{l}$ of DEPC-treated water (Ambion, Inc. Austin, TX). Five $\mu \mathrm{l}$ of nucleic acid was reverse transcribed into cDNA with the following conditions: $25 \mathrm{ng}$ oligo $(\mathrm{dT})_{12-18}, 0.25 \mathrm{mM}$ of each deoxyribonucleotide (Roche Molecular Biochemicals, Indianapolis, IN), 20 units of ribonuclease inhibitor (Roche), 48 units AMV (Roche) or 50 units SuperScript II (Invitrogen Corp. Carlsbad, CA) reverse transcriptase, and buffer provided by the respective manufacturer in a total volume of $20 \mu \mathrm{l}$. The reaction was carried out at $42^{\circ} \mathrm{C}$ for $60 \mathrm{~min}$ and stopped by incubation at $95^{\circ} \mathrm{C}$ for $10 \mathrm{~min}$. Initially, detection of HEV RNA was done with primers described by Meng et al. (23). Five $\mu$ l of cDNA sample was submitted to detection by amplification of a 236 bp sequence of ORF2 in a two-round reaction with the following conditions: $0.2 \mathrm{mM}$ of each deoxyribonucleotide, 0.3 $\mu \mathrm{M}$ of primers JM-2 and JM-5 (primers JM-3 and JM- 4 for the second round reaction), 2.5 units of Taq DNA polymerase (Roche) and supplied buffer (1X buffer was $10 \mathrm{mM}$ Tris-HCl, 1.5 $\mathrm{mM} \mathrm{MgCl}_{2}, 50 \mathrm{mM} \mathrm{KCl}, \mathrm{pH} 8.3$ ) in a total volume of $50 \mu \mathrm{l}$. Two $\mathrm{ml}$ of the first round reaction was pipetted into the second round reaction tube. The reactions were carried out as follows: $94^{\circ} \mathrm{C}$ for $10 \mathrm{~min}$, followed by 50 cycles $(30$ cycles for the nested reaction) at $94^{\circ} \mathrm{C}$ for $30 \mathrm{~s}, 55^{\circ} \mathrm{C}$ for $30 \mathrm{~s}$ and $72^{\circ} \mathrm{C}$ for $1 \mathrm{~min}$, and a final extension step of $72^{\circ} \mathrm{C}$ for $5 \mathrm{~min}$. Five $\mu \mathrm{l}$ of the second round PCR product was separated on a $1 \%$ agarose gel stained with ethidium bromide. Detection was improved with primers designed for amplification of part of ORF2 gene based on alignment of 23 full-length genome sequences (numbering according to Tam et al. (40), based on Burmese strain sequence - accession number M73218): outer primers: JM-2 (nucleotides 6296 to 6318 , ref. 23) and JY7204R - TTTTTTTTTYCAGGGA GCGCG (7204 to 7184); inner primers: JM-3 (6347 to 6369. ref. 23) and JY7120R/RB - CCGRGTTTTACCYACCTTCAT (7120 to 7100). Other primers were also designed and used for amplification and characterization of an extended region of ORF2 sequence: outer primers: JY5259F - GCGGTGGTTTCTG GGGTGAC (5259 to 5278) and JY6582R - TCGGCGGCGGTGA GAGAGAGCCA (6582 to 6560); inner primers: JY5280F GGGTTGATTCTCAGCCCTTC (5280 to 5299) and JY6582 (seminested); for sequencing: previous primers and JY5454F CCCCAGCTGGGGCTGCGCCG (5454 to 5473), JY5473R CGGCGCAGCCCCAGCTGGGG (5473 to 5454), JY5687F AATTATGCCCAGTACCGGGT (5687 to 5706) and JY6369R GGCTCGCCATTGGCTGAGAC(6369 to 6350).

\section{Sequencing and sequence analyses}

PCR products were purified with QIAquick $\mathrm{PCR}$ purification Kit (QIAgen Inc. Valencia, CA) and nucleotide sequencing of PCR products was performed with ABI PRISM 3100 automated DNA sequencer, with the ABI PRISM BigDye Terminator Cycle Sequencing Ready Reaction Kit version 3.11 (Applied Biosystems. Foster City, CA). Sequence data was assembled and analysed with Seqman and MegAlign (DNAStar Inc. Madison, WI). Phylogenetic analysis of $1762 \mathrm{bp}$ sequence, from nucleotide 5336 to 7097 , was performed by the Neighbor-Joining method and 1000 bootstrap replicates with MEGA version 3 (19). The nucleotide sequence of swBRA was deposited at GenBank under accession number EF491206. The following HEV strain sequences (accession numbers) were used in the analyses: genotype 1: C1 (D11902, ref. 2), C2 (L25547. Yin et al., unpublished results), I1 (X98292, ref. 7), Pk (M80581, ref. 43), Bur (M73218, ref. 40); genotype 2: Mx (M74506, ref. 16); genotype 3: US1 (AF060668, ref. 32), US2 (AF060669, ref. 10), swUS (AF082843, ref. 24), JRA (AP003430, ref. 37), Kyrgyz (AF455784, ref. 20); genotype 4: Ct1 (AJ272108, ref. 48), J14 (AB080575, ref. 38), swJ13 (AB097811, ref. 28).

\section{RESULTS}

Comparison of $1762 \mathrm{bp}$ sequence of the ORF2 obtained from the swine HEV found in southeastern Brazil and with members of all known HEV genotypes showed the highest nucleotide (84.4\%) and amino acid (97.1\%) identities with the US HEV strain, which belongs to genotype 3 (Table 1, A and B). The 5' part of the 1762bp sequence overlaps with the 3 ' sequence of ORF3 by 
$142 \mathrm{bp}$. An interesting observation was that, in this overlapping sequence, although the nucleotide identity was higher with the US strain than either the non-overlapping or the entire 1762bp sequences, the amino acid identity was lower, regardless of which ORF is compared. Furthermore, while nucleotide identity varied from 72.5 to $78.8 \%$ when swBRA was compared with sequences from genotypes 1, 2 and 4 (Table 1A), independent on whether the comparison was done with the entire 1762bp sequence or overlapping and non-overlapping regions, amino acid sequence identity presented a wider range, varying from 57.4 to $95.6 \%$.

Phylogenetic analysis, performed with the $1762 \mathrm{bp}$ sequence and sequences of all HEV genotypes as references, revealed that swBRA sequence clustered into the same branch with other swine and human strains of genotype 3 (Fig. 1). Sequences of

Table 1. Partial ORF2 sequence identity analyses of swBRA compared with isolates of all four HEV genotypes.

A) Nucleotide sequence identity (\%)

\begin{tabular}{cccc}
\hline & 1762bp & $\begin{array}{c}\text { 1620bp non- } \\
\text { overlapping } \\
\text { sequence }\end{array}$ & $\begin{array}{c}\text { 142bp ORF2/ORF3 } \\
\text { overlapping } \\
\text { sequence }\end{array}$ \\
\hline $\begin{array}{c}\text { Genotype 1 } \\
\text { (Burma) }\end{array}$ & 78.7 & 78.8 & 78.2 \\
$\begin{array}{c}\text { Genotype 2 } \\
\text { (Mexico) }\end{array}$ & 76.7 & 77.1 & 72.5 \\
$\begin{array}{c}\text { Genotype 3 } \\
\text { (US) }\end{array}$ & 84.4 & 84.0 & 89.4 \\
$\begin{array}{c}\text { Genotype 4 } \\
\text { (China) }\end{array}$ & 78.2 & 78.5 & 75.4 \\
\hline
\end{tabular}

B) Amino acid sequence identity (\%)

\begin{tabular}{ccccc}
\hline & \multicolumn{2}{c}{ ORF2 } & \multicolumn{3}{c}{$\begin{array}{c}\text { ORF2/ORF3 } \\
\text { overlapping } \\
\text { sequence }\end{array}$} \\
\cline { 2 - 5 } & 1762bp & $\begin{array}{c}\text { 1620bp non- } \\
\text { overlapping } \\
\text { sequence }\end{array}$ & $\begin{array}{c}\text { 142bp } \\
\text { ORF2 }\end{array}$ & $\begin{array}{c}\text { 142bp } \\
\text { ORF3 }\end{array}$ \\
\hline $\begin{array}{c}\text { Genotype 1 } \\
\text { (Burma) } \\
\text { Genotype 2 } \\
\text { (Mexico) }\end{array}$ & 93.0 & 95.4 & 66.0 & 66.0 \\
$\begin{array}{c}\text { Genotype 3 } \\
\text { (US) }\end{array}$ & 97.1 & 98.1 & 85.1 & 85.1 \\
$\begin{array}{c}\text { Genotype 4 } \\
\text { (China) }\end{array}$ & 93.2 & 95.6 & 66.0 & 68.1 \\
\hline
\end{tabular}

the strains used to construct the phylogenetic tree of genotypes 1 and 4 were of Asian strains, including Pakistani, Indian and Burmese strains. The member of genotype 2 was from Mexico. Another swine strain sequence used in the analysis, found in Japan, belonged to genotype 4 . Strains of genotype 3 were found in the US, Japan, and Europe.

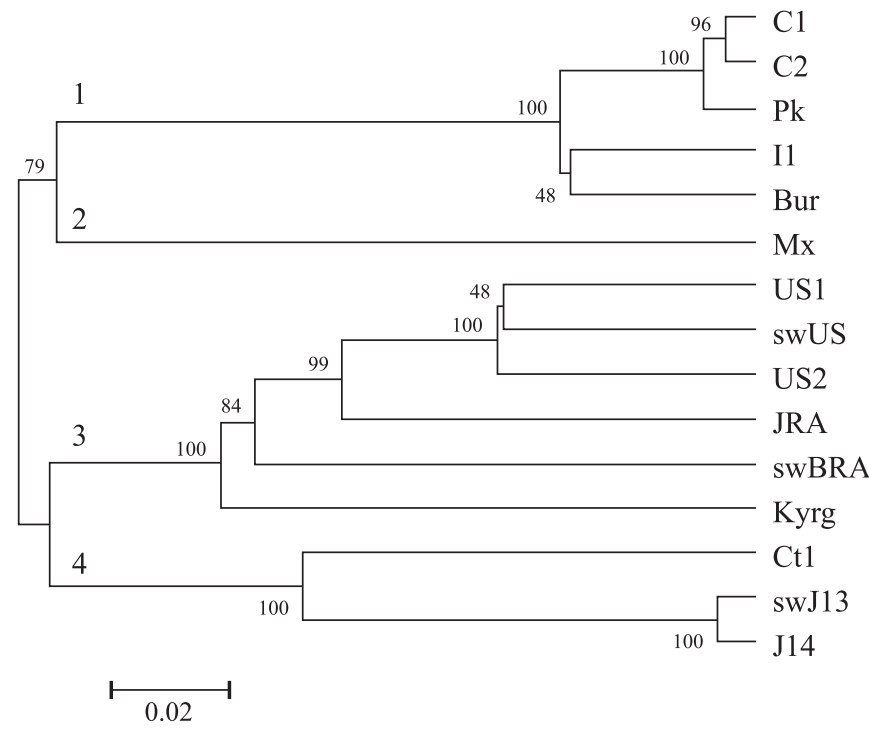

Figure 1. Phylogenetic tree based on the $1720 \mathrm{nt}$ long fragment in ORF2 including sequences of isolates from all four genotypes. Identification and accession numbers of the isolates are described in Material and Methods. Bootstrap values (\%) are indicated at the nodes and genetic distance per nucleotide site is shown by horizontal bar at the bottom. Abbreviations are: $\mathrm{C} 1, \mathrm{C} 2$ and $\mathrm{Ct} 1$ - Chinese/Taiwanese isolates; Pk - Pakistan's isolate; I - Indian isolate; Bur - Burmese isolate; $\mathrm{Mx}$ - Mexican isolate; US1, US2 and swUS - US isolate; JRA, J14 and swJ13 Japanese isolate; Kyrg - Kyrgyzstan isolate; swBRA - Brazilian isolate (this study). Prefix 'sw' in the abbreviations denotes sequences of swine HEV isolates.

\section{DISCUSSION}

We report here, for the first time, the molecular characterization of a hepatitis $E$ virus from Brazil. In spite of lack of molecular descriptions, serological evidences of infections have been reported for humans $(6,8,12,22,29,42)$ and other animals (46). Since anti-HEV immunoglobulin $\mathrm{G}(\operatorname{IgG})$ has been detected in approximately $94 \%$ of 20 -week old pigs in New Zealand (11) and these animals are thought to be a source for transmission of HEV to humans, in order to detect and characterize an HEV RNA in Brazil, we collected feces of pigs at 
ages ranging from four to 14 weeks old. We tested samples from eight pigs of one farm and detected HEV RNA in seven of them. Nucleotide and amino acid sequence identities of this isolate, swBRA, were highest with HEV reference sequences belonging to genotype 3, regardless of the ORF2 region analyzed. As proposed by Worm et al. (49), nucleotide identity higher than $80 \%$, as we observed with swBRA and other isolates of genotype 3 , places both sequences in the same genotypic group. Stool samples of pigs from two other farms were also tested. We detected HEV RNA only in samples of pigs from one of these farms and its nucleotide sequence showed highest identity with the swBRA isolate (results not shown).

Sporadic cases of hepatitis $E$ in regions where prevalence is low led to the hypothesis that this disease may be a zoonosis. Hepatitis E virus strains genetically related to human HEV have been found in different animals $(13,24,41)$ and, in particular the swine HEV, which showed highest nucleotide identity with human isolates, phylogenetic analyses placed swine and human HEV strains within the same branches, suggesting that they are closely related $(15,24,39,45)$. This hypothesis was confirmed by direct evidence of hepatitis $E$ infections in people after consumption of raw deer meat, in which viruses recovered from the meat and from the patients had identical sequences (41). Furthermore, HEV RNA was found in approximately $1.9 \%$ of pig livers sold in grocery stores in Japan and partial nucleotide sequence of HEV found in two of these livers was $100 \%$ identical to HEV sequences found in two patients (50). These findings suggest that consumption of raw or undercooked meat from infected animals may transmit HEV to humans and may have been the source of hepatitis $\mathrm{E}$ virus in patients who had had history of consuming pig liver few weeks before the disease onset. Interestingly, although all four HEV genotypes have been found in humans, only HEV of genotypes 3 and 4 have been described in pigs $(15,24,39,45)$. Furthermore, human HEV isolates of genotypes 1 and 2 did not infect pigs in infection experiments (25). On the other hand, swine HEV of genotype 3 successfully infected chimpanzees (26), experimental surrogates of humans. These observations suggest that pigs may be the source of transmissions to humans exclusively of HEV genotypes 3 and 4. Finally, presence of other HEV genotypes in Brazil still needs to be investigated.

\section{ACKNOWLEDGMENTS}

We thank Drs. Yury Khudyakov and Howard Fields, of Division of Viral Hepatitis, CDC, Atlanta, GA, Profs. Auro Nomizo, Ana Lúcia C. Darini, Lúcia H. Faccioli, Sérgio A. Uyemura, Regina C. Cândido, Maria de Lourdes P. Bianchi, technicians Nancy Rodrigues, Tânia Ogasawara and João José Franco, of DACTB/FCFRP/USP, and Profs. Luiz Tadeu M. Figueiredo and Eurico de Arruda Neto, for their invaluable assistance in this study.

\section{RESUMO}

\section{Caracterização molecular do vírus suíno da hepatite $\mathbf{E}$ (VHE) encontrado no Sudeste do Brasil}

Apesar de evidências sorológicas da presença do vírus da hepatite $\mathrm{E}$ (VHE) em humanos ou outros animais, até o presente estudo o vírus não havia sido detectado e a caracterização molecular da cepa que circula no Brasil não havia sido descrita. Assim, amostras de fezes de porcos jovens foram colhidas e analizadas quanto a presença do ARN do VHE por RT-PCR, utilizando-se oligonucleotídeos para amplificação da seqüência parcial do ORF2 viral. Análise filogenética realizada com a sequiência obtida dos produtos amplificados revelou que a cepa encontrada apresentou relação próxima com cepas do genótipo 3 que são detectadas com freqüência em porcos. Análises das seqüências nucleotídicas realizadas com todo o segmento amplificado, com somente o segmento sobreposto do ORF2/ ORF3 e aquele sem sobreposição do ORF2, em comparação com isolados de genótipos conhecidos, mostraram maior identidade com o isolado encontrado nos Estados Unidos (US) do genótipo 3. De maneira semelhante, análises da seqüência de aminoácidos realizadas com os mesmos segmentos também mostraram maior identidade com o isolado de genótipo 3 . Presença ou não do vírus de genótipo 4 , que também infecta porcos, ainda necessita ser verificada. Da mesma forma, cepas do VHE que infectam humanos ainda necessitam ser detectadas e caracterizadas.

Palavras chaves: hepatites virais, vírus da hepatite E, VHE, virologia molecular

\section{REFERENCES}

1. Alvarez-Munoz, M.T.; Torres, J.; Damasio, L.; Gomez, A.; TapiaConyer, R.; Munoz, O. (1999). Seroepidemiology of hepatitis E virus infection in Mexican subjects 1 to 29 years of age. Arch. Med. Res., 30, 251-254.

2. Aye, T.T.; Uchida, T.; Ma, X.Z.; Iida, F.; Shikata, T.; Zhuang, H.; Win, K.M. (1992). Complete nucleotide sequence of a hepatitis E virus isolated from the Xinjiang epidemic (1986-1988) of China. Nucleic Acids Res., 20, 3512.

3. Balayan, M.S.; Andjaparidze, A.G.; Savinskaya, S.S.; Ketiladze, E.S.; Braginsky, D.M.; Savinov, A.P.; Poleschuk, V.F. (1983). Evidence for a virus in non-A; non-B hepatitis transmitted via the fecal-oral route. Intervirology, 20, 23-31.

4. Bi, S.L.; Purdy, M.A.; McCaustland, K.A.; Margolis, H.S.; Bradley, D.W. (1993). The sequence of hepatitis E virus isolated directly from a single source during an outbreak in China. Virus Res., 28, 233247.

5. Cooper, K.; Huang, F.F.; Batista, L.; Rayo, C.D.; Bezanilla, J.C.; Toth, T.E.; Meng, X.J. (2005). Identification of genotype 3 hepatitis $\mathrm{E}$ virus (HEV) in serum and fecal samples from pigs in Thailand and Mexico; where genotype 1 and $2 \mathrm{HEV}$ strains are prevalent in the respective human populations. J. Clin. Microbiol., 43, 16841688 . 
6. De Paula, V.S.; Arruda, M.E.; Vitral, C.L.; Gaspar, A.M.C. (2001). Seroprevalence of viral hepatitis in riverine communities from the western region of the Brazilian Amazon basin. Mem. Inst. Oswaldo Cruz, 96, 1123-1128.

7. Donati, M.C.; Fagan, E.A.; Harrison, T.J. (1997). Sequence analysis of full length HEV clones derived directly from human liver in fulminant hepatitis E. In: Rizzetto, M.; Purcell, R.H.; Gerin, J.L.; Verme, G. (eds.). Viral hepatitis and liver disease. Edizioni Minerva Medica, Torino, Italy, p.313-316.

8. Dos Santos, D.C.M.; Souto, F.J.D.; Dos Santos, D.R.L.; Vitral, C.L.; Gaspar, A.M.C. (2002). Seroepidemiological markers of enterically transmitted viral hepatits $\mathrm{A}$ and $\mathrm{E}$ in individuals living in a community located in the North area of Rio de Janeiro, RJ, Brazil. Mem. Inst. Oswaldo Cruz, 97, 637-640.

9. Emerson, S.U.; Purcell, R.H. (2003). Hepatitis E virus. Rev. Med. Virol., 13, 145-154.

10. Erker, J.C.; Desai, S.M.; Schlauder, G.G.; Dawson, G.J.; Mushahwar, I.K. (1999). A hepatitis E virus variant from the United States: molecular characterization and transmission in cynomolgus macaques. J. Gen. Virol., 80, 681-690.

11. Garkavenko, O.; Obriadina, A.; Meng, J.; Anderson, D.A.; Bernard, H.J.; Schroeder, B.A.; Khudyakov, Y.E.; Fields, H.A.; Croxson, M.C. (2001). Detection and characterization of swine hepatitis $\mathrm{E}$ virus in New Zealand. J. Med. Virol., 65, 525-529.

12. Gonçales, N.S.L.; Pinho, J.R.R.; Moreira, R.C.; Saraceni, C.P.; Spina, A.M.M.; Stucchi, R.B.; Ribeiro Filho, A.D.; Magna, L.A.; Gonçales Júnior, F.L. (2000). Hepatitis E virus immunoglobulin G antibodies in different populations in Campinas, Brazil. Clin. Diagn. Lab. Immunol., 7, 813-816.

13. Haqshenas, G.; Shivaprasad, H.L.; Woolcock, P.R.; Read, D.H.; Meng, X.J. (2001). Genetic identification and characterization of a novel virus related to human hepatitis $\mathrm{E}$ virus from chickens with hepatitissplenomegaly syndrome in the United States. J. Gen. Virol., 82, 2449-2462.

14. Harrison, T.J. (1999). Hepatitis E virus - an update. Liver, 19, 171-176.

15. Hsieh, S.Y.; Meng, X.J.; Wu, Y.H.; Liu, S.T.; Tam, A.W.; Lin, D.Y.; Liaw, Y.F. (1999). Identity of a novel swine hepatitis $E$ virus in Taiwan forming a monophyletic group with Taiwan isolates of human hepatitis E virus. J. Clin. Microbiol., 37, 3828-3834.

16. Huang, C.C.; Nguyen, D.; Fernandez, J.; Yun, K.Y.; Fry, K.E.; Bradley, D.W.; Tam, A.W.; Reyes, G.R. (1992). Molecular cloning and sequencing of the Mexico isolate of hepatitis E virus (HEV). Virology, 191, 550-558.

17. Krawczynski, K.; Kamili, S.; Aggarwal, R. (2001). Global epidemiiology and medical aspects of hepatitis E. Forum (Genova) 11, 166-179.

18. Koonin, E.V.; Gorbalenya, A.E.; Purdy, M.A.; Rozanov, M.N.; Reyes, G.R.; Bradley, D.W. (1992). Computer-assisted assignment of functional domains in the nonstructural polyprotein of hepatitis $\mathrm{E}$ virus: delineation of an additional group of positive-strand RNA plant and animal viruses. Proc. Natl. Acad. Sci. USA, 89, 8259-8263.

19. Kumar, S.; Tamura, K.; Nei, M. (2004). MEGA3: Integrated software for Molecular evolutionary genetics analysis and sequence alignment. Version 3.1. Briefings in Bioinformatics, 5, 150-163.

20. Lu, L.; Drobeniuc, J.; Kobylnikov, N.; Usmanov, R.K.; Robertson, B.H.; Favorov, M.O.; Margolis, H.S. (2004). Complete sequence of a Kyrgyzstan swine hepatitis E virus (HEV) isolated from a piglet thought to be experimentally infected with human HEV. J. Med. Virol., 74, 556-562.

21. Lu, L.; Li, C.; Hagedorn, C.H. (2006). Phylogenetic analysis of global hepatitis $\mathrm{E}$ virus sequences: genetic diversity; subtypes and zoonosis. Rev. Med. Virol. 16, 5-36.

22. Lyra, A.C.; Pinto, J.R.R.; Silva, L.K.; Sousa, L.; Saraceni, C.P.; Braga, E.L.; Pereira, J.E.; Zarife, M.A.S.; Reis, M.G.; Lyra, L.G.C.; Da Silva, L.C.; Carrilho, F.J. (2005). Braz. J. Med. Biol. Res., 38, 767-775.
23. Meng, J.; Dai, X.; Chang, J.C.; Lopareva, E.; Pillot, J.; Fields, H.A.; Khudyakov, Y.E. (2001). Identification and characterization of the neutralization epitope(s) of the hepatitis E virus. Virology, 288, 203-211

24. Meng, X.J.; Purcell, R.H.; Halbur, P.G.; Lehman, J.R.; Webb, D.M.; Tsareva, T.S.; Haynes, J.S.; Thacker, B.J.; Emerson, S.U. (1997). A novel virus in swine is closely related to the human hepatitis $\mathrm{E}$ virus. Proc. Natl. Acad. Sci. USA, 94, 9860-9865.

25. Meng, X.J.; Halbur, P.G.; Haynes, J.S.; Tsareva, T.S.; Bruna, J.D.; Royer, R.L.; Purcell, R.H.; Emerson, S.U. (1998(. Experimental infection of pigs with the newly identified swine hepatitis E virus (swine HEV); but not with human strains of HEV. Arch. Virol., 143 , 1405-1415.

26. Meng, X.J.; Halbur, P.G.; Shapiro, M.X.; Govindarajan, S.; Bruna, J.D.; Mushahwar, I.K.; Purcell, R.H.; Emerson, S.U. (1998). Genetic and experimental evidence for cross-species infection by swine hepatitis E virus. J. Virol., 72, 9714-9721.

27. Munné, M.S.; Vladimirsky, S.; Otegui, L.; Castro, R.; Brajterman, L.; Soto, S.; Guarnera, E.; Molina, V.; Monfellano, M.; Schlauder, G.G.; González, J.E. (2006). Identification of the first strain of swine hepatitis E virus in South America and prevalence of anti-HEV antibodies in swine in Argentina. J. Med. Virol., 78, 1579-1583.

28. Nishizawa, T.; Takahashi, M.; Mizuo, H.; Miyajima, H.; Gotanda, Y.; Okamoto, H. (2003). Characterization of Japanese swine and human hepatitis E virus isolates of genotype IV with $99 \%$ identity over the entire genome. J. Gen. Virol., 84, 1245-1251.

29. Parana, R.; Cotrim, H.P.; Cortey-Boennec, M.L.; Trepo, C.; Lyra, L.(1997). Prevalence of hepatitis E virus IgG antibodies in patients from a referral unit of liver diseases in Salvador, Bahia, Brazil. Am. J. Trop. Med. Hyg., 57, 60-61.

30. Pina, S.; Buti, M.; Cotrina, M.; Piella, J.; Girones, R. (2000). HEV identified in serum from humans with acute hepatitis and in sewage of animal origin in Spain. J. Hepat, 33, 826-833.

31. Sambrook, J.; Russell, D.W. (2001). Molecular Cloning: A Laboratory Manual. Third edition. Cold Spring Harbor Laboratory Press. Cold Spring Harbor; New York.

32. Schlauder, G.G.; Dawson, G.J.; Erker, J.C.; Kwo, P.Y.; Knigge, M.F.; Smalley, D.L.; Rosenblatt, J.E.; Desai, S.M.; Mushahwar, I.K. (1998). The sequence and phylogenetic analysis of a novel hepatitis $\mathrm{E}$ virus isolated from a patient with acute hepatitis reported in the United States. J. Gen. Virol., 79, 447-456.

33. Schlauder, G,G,; Desai, S.M.; Zanetti, A.R.; Tassoupoulos, N.C.; Mushahwar, I.K. (1999). Novel hepatitis E virus (HEV) isolates from Europe: evidence for additional genotypes of HEV. J. Med. Virol., 57, 243-251.

34. Schlauder, G.G.; Frider, B.; Sookoian, S.; Castaño, G.C.; Mushahwar, I.K. (2000). Identification of 2 novel isolates of hepatitis $E$ virus in Argentina. J. Infect. Dis., 182, 294-297.

35. Schlauder, G.G.; Mushahwar, I.K. (2001). Genetic Heterogeneity of hepatitis E virus. J. Med. Virol., 65, 282-292.

36. Smith, J.L. (2001). A review of hepatitis E virus. J. Food Prot., 64 572-586.

37. Takahashi, K.; Iwata, K.; Watanabe, N.; Hatahara, T.; Ohta, Y.; Baba, K.; Mishiro, S. (2001). Full-genome nucleotide sequence of a hepatitis E virus strain that may be indigenous to Japan. Virology, 287, 9-12.

38. Takahashi, M.; Nishizawa, T.; Yoshikawa, A.; Sato, S.; Isoda, N.; Ido, K.; Sugano, K.; Okamoto, H. (2002). Identification of two distinct genotypes of hepatitis E virus in a Japanese patient with acute hepatitis who had not traveled abroad. J. Gen. Virol., 83, 1931-1940.

39. Takahashi, M.; Nishizawa, T.; Miyajima, H.; Gotanda, Y.; Iita, T.; Tsuda, F.; Okamoto, H. (2003). Swine hepatitis E virus strains in Japan form four Phylogenetic clusters comparable with those of Japanese isolates of human hepatitis E virus. J. Gen. Virol., 84, 851862. 
40. Tam, A.W.; Smith, M.M.; Guerra, M.E.; Huang, C.C.; Bradley, D.W.; Fry, K.E.; Reyes, G.R. (1991). Hepatitis E virus (HEV): molecular cloning and sequencing of the full-length viral genome. Virology, $185,120-131$.

41. Tei, S.; Kitajima, N.; Takahashi, K.; Mishiro, S. (2003). Zoonotic transmission of hepatitis $\mathrm{E}$ virus from deer to human beings. Lancet, $362,371-373$.

42. Trinta, K.S.; Liberto, M.I.M.; De Paula, V.S.; Yoshida, C.F.T.; Gaspar, A.M.C. (2001). Hepatitis E virus infection in selected Brazilian populations. Mem. Inst. Oswaldo Cruz, 96, 25-29.

43. Tsarev, S.A.; Emerson, S.U.; Reyes, G.R.; Tsareva, T.S.; Legters, L.J.; Malik, I.A.; Iqbal, M.; Purcell, R.H. (1992). Characterization of a prototype strain of hepatitis E virus. Proc. Natl. Acad. Sci. USA, 89, 559-563.

44. Van Cuyck-Gandré, H.; Zhang, H.Y.; Tsarev, S.A.; Warren, R.L.; Caudill, J.D.; Snellings, N.J.; Bégot, L.; Innis, B.L.; Longer, C.F. (2000). Short report: phylogenetically distinct hepatitis E viruses in Pakistan. Am. J. Trop. Med. Hyg., 62, 187-189.

45. Van der Poel, W.H.M.; Verschoor, F.; Van der Heide, R.; Herrera, M.I.; Vivo, A.; Kooreman, M.; Husman, A.M.R. (2001). Hepatitis E virus sequences in swine related to sequences in human, the Netherlands. Emerging Infectious Diseases, 7, 970-976.
46. Vitral, C.L.; Pinto, M.A.; Lewis-Ximenez, L.L.; Khudyakov, Y.E.; Dos Santos, D.R.; Gaspar, A.M.C. (2005). Serological evidence of hepatitis E virus infection in different animal species from the Southeast of Brazil. Mem. Inst. Oswaldo Cruz, 100, 117-122.

47. Wang, Y.; Ling, R.; Erker, J.C.; Zhang, H.; Li, H.; Desai, S.; Mushahwar, I.K.; Harrison, T.J. (1999). A divergent genotype of hepatitis E virus in Chinese patients with acute hepatitis. J. Gen. Virol., 80, 169-177.

48. Wang, Y.; Zhang, H.; Ling, R.; Li, H.; Harrison. T.J. (2000). The complete sequence of hepatitis $\mathrm{E}$ virus genotype 4 reveals an alternative strategy for translation of open reading frames 2 and 3. J. Gen. Virol., 81, 1675-1686.

49. Worm, H.C.; Van der Poel, W.H.M.; Brandstätter, G. (2002). Hepatitis E: an overview. Microbes and Infection, 4, 657-666.

50. Yazaki, Y.; Mizuo, H.; Takahashi, M.; Nishizawa, T.; Sasaki, N.; Gotanda, Y.; Okamoto, H. (2003). Sporadic acute or fulminant hepatitis $\mathrm{E}$ in Hokkaido, Japan, may be food-borne, as suggested by the presence of hepatitis E virus in pig liver as food. J. Gen. Virol., 84, 2351-2357.

51. Yin, S.; Tsarev, S.A.; Purcell, R.H.; Emerson, S.U. (1993). Partial sequence comparison of eight new Chinese strains of hepatitis E virus suggests the genome sequence is relatively stable. J. Med. Virol., $41,230-241$. 